УДК 330.34:339.56(045)

\title{
РОЗВИТОК ТОРГОВЕЛЬНО-ІНВЕСТИЦІЙНИХ ВІДНОСИН УКРАЇНИ 3 КРАЇНАМИ-ЧЛЕНАМИ ЄС
}

\section{DEVELOPMENT OF TRADE AND INVESTMENT RELATIONS OF UKRAINE WITH EU MEMBER STATES}

\author{
Сердюков Костянтин Георгійович \\ доктор економічних наук, доцент, \\ Університет митної справи та фінансів \\ ORCID: https://orcid.org/0000-0002-3834-8761 \\ Екзархова Евеліна Анатоліївна \\ здобувач вищої освіти, \\ Університет митної справи та фрінансів \\ ORCID: https://orcid.org/0000-0003-1446-3746
}

\section{Serdyukov Kostyantyn, Ekzarkhova Evelina University of Customs and Finance}

\begin{abstract}
Стаття присвячена дослідженню розвитку торговельно-інвестиційних відносин України з країнами-членами ЄС. Проаналізовано сучасний стан економічного співробітництва України з країнами ЄС за допомогою дослідження динаміки їх зовнішньої торгівлі товарами та послугами у розрізі експортних й імпортних операцій. Виявлено основні категорії зовнішньої торгівлі товарами та послугами України з ЄС. Визначено лідерів серед країн ЄС за експортом з України й імпортом в Україну товарів і послуг. Досліджено обсяги накопичених прямих зарубіжних інвестицій (ПЗІ) в Україні. Виявлено найбільших інвесторів України з ЄС та їх питому вагу в загальному обсязі накопичених ПЗІ. Проаналізовано обсяги прямих іноземних інвестицій (ПІІ) з України до ЄС. Подано пріоритетні напрями активізації торгівлі та можливості інвестиційного співробітництва України 3 країнами-членами ЄС.
\end{abstract}

Ключові слова: зовнішня торгівля, експорт, імпорт, інвестиційне співробітництво, торговельно-інвестиційні відносини.

Статья посвящена исследованию развития торгово-инвестиционных отношений Украины со странамичленами ЕС. Проанализировано современное состояние экономического сотрудничества Украины со странами ЕС посредством исследования динамики их внешней торговли товарами и услугами в разрезе экспортных и импортных операций. Выявлены основные категории внешней торговли товарами и услугами Украины c EC. Определены лидеры среди стран EC по экспорту из Украины и импорту в Украину товаров и услуг. Исследованы объемы накопленных прямых зарубежных инвестиций (ПЗИ) в Украине. Выявлены крупнейшие инвесторы Украины из ЕС и их удельный вес в общем объеме накопленных ПЗИ. Проанализированы объемы прямых иностранных инвестиций из Украины в ЕС. Представлены приоритетные направления активизации торговли и возможности инвестиционного сотрудничества Украины со странами-членами ЕС.

Ключевые слова: внешняя торговля, экспорт, импорт, инвестиционное сотрудничество, торгово-инвестиционные отношения.

The article is devoted to the study of the development of trade and investment relations of Ukraine with EU member states. The current state of economic cooperation between Ukraine and the EU is analyzed by studying the dynamics of their foreign trade in goods and services. The dynamics of foreign trade turnover of goods of Ukraine with EU member states, volumes of their exports and imports are determined. The share of EU in exports and imports of Ukrainian goods and general trends in trade in goods between Ukraine and EU member states are studied. The main commodity categories of Ukrainian exports and imports in Ukraine's trade with EU member states are presented. The leaders among EU member states in terms of exports from Ukraine and imports to Ukraine are identified. The dynamics of the volume of foreign trade turnover of services of Ukraine with the EU member states, volumes of their exports and imports are studied. The share of the EU in exports and imports of services of Ukraine and general trends in trade in services between Ukraine and EU member states are determined. The main categories of services exported from Ukraine to the EU and imported from the EU to Ukraine are presented. The leaders among 
the EU member states in terms of exports from Ukraine and imports of services to Ukraine are listed. The volumes of accumulated foreign direct investment (share capital) in Ukraine are studied. The largest investors of Ukraine among EU member states and their share in the total amount of accumulated foreign direct investment (share capital) are identified. The volumes of foreign direct investment (share capital) from Ukraine to EU member states are analyzed and it is determined where most foreign direct investments (share capital) come from Ukraine. Priority areas for intensifying foreign trade are presented, which will help to strengthen Ukraine's trade relations with EU member states, increase their mutual trade and deepen trade cooperation. Ukraine's investment opportunities and investment attractiveness factors that will contribute to the deepening of investment cooperation between Ukraine and EU member states are identified.

Keywords: foreign trade, export, import, investment cooperation, trade and investment relations.

Постановка проблеми. Співробітництво України з країнами-членами ЄС сприяє зміцненню їх зовнішньоекономічних зв'язків та збільшенню обсягів торгівлі й інвестицій, що має значний вплив на розвиток економіки України. Аналіз сучасного стану торговельноінвестиційних відносин України з країнами $€ С$ сприятиме визначенню пріоритетних напрямів активізації торгівлі та можливостей інвестування для формування перспектив і поглиблення їх подальшого співробітництва.

Аналіз останніх досліджень і публікацій. Дослідженням міжнародної торгівлі та міжнародних інвестицій присвячено праці багатьох вітчизняних і зарубіжних вчених, серед яких А. Голіков [2], О. Довгаль [2], В. Новицький [5], Т. Майорова [3] та ін., а дослідженнями торговельних й інвестиційних відносин України $з$ країнами $€ С$ займаються такі вчені як: Р. Бойчук [1], В. Романенко [7], Л. Лебедева [7], Т. Яхно [8], 3. Макогін [8] та ін.

Формулювання цілей статті. Метою статті $€$ аналіз сучасного стану торговельноінвестиційних відносин України 3 країнамичленами $€ C$, розробка пропозицій щодо їх подальшого співробітництва.

Виклад основного матеріалу дослідження. Зростання зовнішньої торгівлі товарами України 3 країнами ЄС динамічно відбувалося до 2019 р. включно, після чого у 2020 р. відбулося скорочення обсягів торгівлі, зокрема внаслідок впливу пандемії COVID-19, яка в цілому призвела до скорочення світової економіки, збільшення рівня безробіття, занепаду багатьох галузей промисловості.

Обсяг торгівлі товарами між Україною та $€ C$ (див. рис. 1) за результатами 2020 р. склав 42,5 млрд дол., що на 7,2\% менше ніж у 2019 р., однак ЄС залишається ключовим торговельним партнером України із часткою $41 \%$.

Питома вага країн $€$ в в експорті товарів з України у 2020 р. становила 37,8\% порівняно 3 41,6\% у 2019 р. Так, у 2018 р. доля експорту товарів з України до країн ЄС становила 42,7\%, що відображає загальну тенденцію поступового зменшення частки країн $€$ С в експорті українських товарів.

В експорті України до ЄС у 2020 р. (див. рис. 2) домінували чорні метали, електричні машини й устаткування, жири та олії тваринного або рослинного походження, зернові культури, руди і шлаки, які разом становили більше половини усього експорту товарів до країн $€$.

Частка ЄС у імпорті товарів в Україну у 2020 р. зросла на $2 \%$ - до 44\%. У імпорті 3 $€ С$ в Україну у 2020 р. (див. рис. 3) домінували такі товарні категорії: реактори ядерні, котли, машини; засоби наземного транспорту, крім залізничного; електричні машини й устаткування; фрармацевтична продукція, які разом становили майже половину усього імпорту товарів з ЄС. Серед країн ЄС у 2020 р. (див.

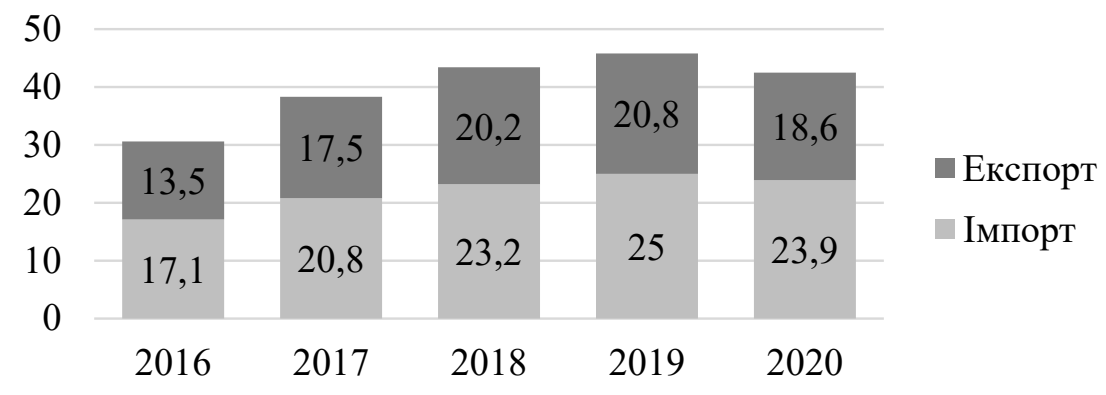

Рис. 1. Зовнішньоторговельний оборот товарів України з $€$, млрд дол. 

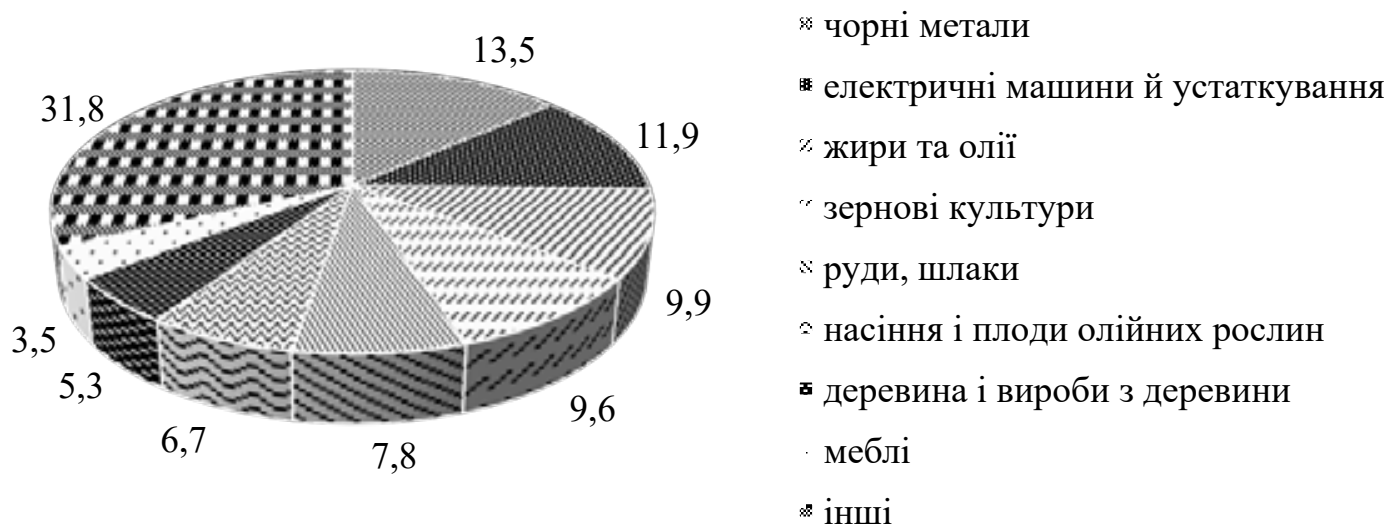

Рис. 2. Товарні категорії українського експорту в ЄС у 2020 р., \% Джерело: побудовано авторами за даними [6]

табл. 1) лідером експорту товарів з України стала Польща, яка є другим найбільшим експортером товарів України після Китаю. До десятки найбільших країн-експортерів українських товарів, окрім Польщі, входять Німеччина, Італія та Нідерланди. До десятки найбільших імпортерів товарів в Україну у 2020 р. увійшло п'ять країн ЄС: Німеччина, Польща, Італія, Франція та Угорщина. Найбільшими країнами-імпортерами товарів з України у ЄС також стали Словаччина, Чехія, Литва, Нідерланди та Іспанія.

Обсяг торгівлі послугами між Україною та країнами-членами $Є С$ щороку збільшувався до спаду у 2020 р., коли внаслідок впливу пандемії COVID-19 він скоротився на $14 \%$ і склав 7,1 млрд дол. (див. рис. 4).

Експорт послуг з України до ЄС у 2020 р. знизився на 4,8\% та становив 4,3 млрд дол. Частка країн ЄС в експорті послуг з України після 30\% у 2019 р. збільшилась до 38\% у
2020 р. Проте це сталося за рахунок сильного зменшення загального експорту послуг на 4 млрд дол. і менш значного скорочення експорту послуг до ЄС - всього на 200 млн дол. До ЄС з України у 2020 р. надійшло 40\% усіх послуг, основними категоріями експорту послуг стали (див. рис. 5): послуги у сорері телекомунікацій, транспортні, послуги з переробки матеріальних ресурсів, ділові послуги.

Імпорт послуг в Україну з ЄС у 2020 р. скоротився на 24,3\% відносно рівня 2019 р. до 2,8 млрд дол. Незважаючи на те, що частка країн $€ С$ в імпорті послуг України зменшилася на 3\% до рівня 54\%, ЄС залишається ключовим імпортером послуг в Україну. Основні категорії імпорту послуг у 2020 р. зображено на рис. 6.

У табл. 2 наведено лідерів експорту та імпорту послуг України серед країн ЄС у 2020 р.

Обсяг прямих зарубіжних інвестицій (акціонерного капіталу) з країн ЄС (див. рис. 7) має тенденцію до зростання.
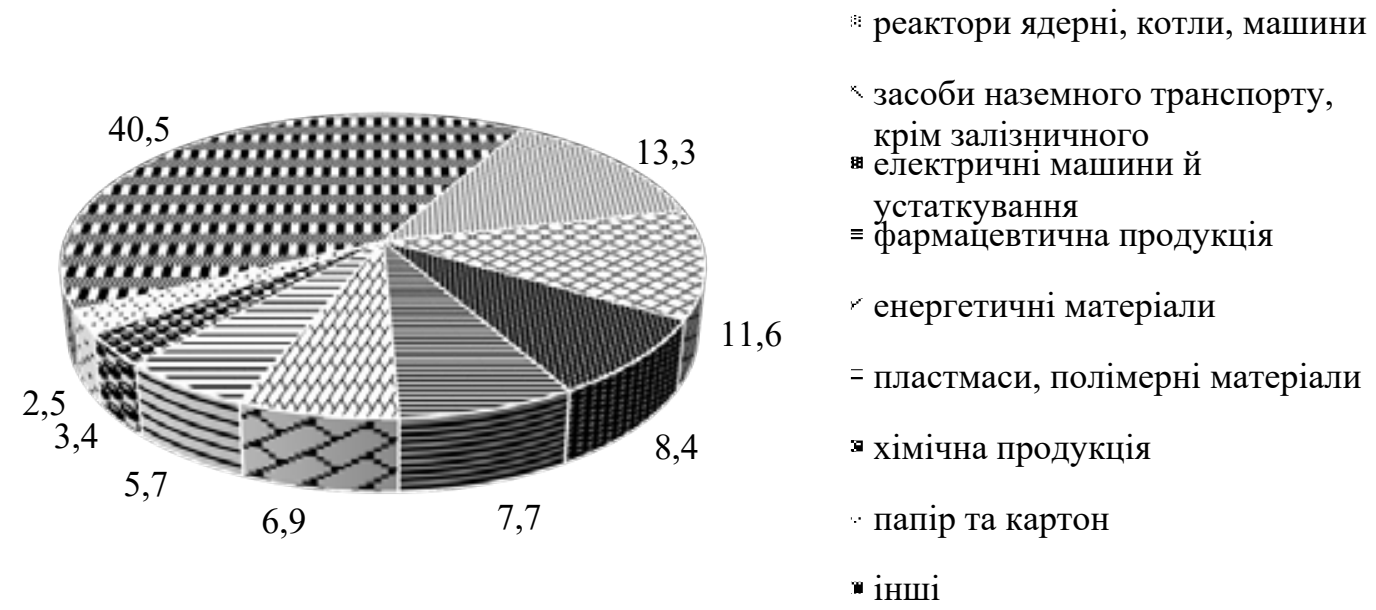

Рис. 3. Товарні категорії українського імпорту з ЄС у 2020 р., \% Джерело: побудовано авторами за даними [6] 
Топ-10 експортерів та імпортерів товарів серед країн ЄС у 2020 р.

\begin{tabular}{|l|c|l|c|}
\hline \multicolumn{1}{|c|}{ Країна-експортер } & $\begin{array}{c}\text { Обсяг експорту } \\
\text { товарів 3 України, } \\
\text { тис. дол. }\end{array}$ & \multicolumn{1}{|c|}{ Країна-імпортер } & $\begin{array}{c}\text { Обсяг імпорту } \\
\text { товарів в Україну, } \\
\text { тис. дол. }\end{array}$ \\
\hline Польща & 3272683,1 & Німеччина & 5339677,7 \\
\hline Німеччина & 2071739,4 & Польща & 4140911,8 \\
\hline Італія & 1928906,3 & Італія & 2128733,9 \\
\hline Нідерланди & 1802205,9 & Франція & 1467709,5 \\
\hline Угорщина & 1263810,4 & Угорщина & 1399536,4 \\
\hline Іспанія & 1250213,7 & Словаччина & 1143401,5 \\
\hline Румунія & 1080954,2 & Чехія & 961721,3 \\
\hline Чехія & 826278,3 & Литва & 813405,6 \\
\hline Велика Британія & 666851,9 & Нідерланди & 750840,0 \\
\hline Франція & 592395,2 & Іспанія & 735137,4 \\
\hline
\end{tabular}

Джерело: побудовано авторами за даними [6]

Найбільшими іноземними інвесторами України є Кіпр, Нідерланди і Велика Британія. Обсяг ПЗІ (акціонерного капіталу) з Кіпру у 2019 р. становив 10,4 млрд дол., 3 Нідерландів - 8,3 млрд дол., а з Великої Британії - 2,1 млрд дол. Серед країн ЄС важливими інвесторами для України (див. рис. 8) також $€$ Німеччина й Австрія [2; 8].

Питома вага країн $Є С$ в обсязі акціонерного капіталу, накопиченого в Україні, станом на кінець 2019 р. склала 79\%. Того ж року обсяг ПЗІ (акціонерного капіталу) з Кіпру становив 37\%, з Нідерландів - 29\%, Великобританії та Німеччини - по 7\%, з Австрії - 4\%, іншим країнам ЄС належить $16 \%$.

Обсяг прямих іноземних інвестицій (акціонерного капіталу) з України (див. рис. 9) у 2019 р. скоротився на 21,7 млн дол., порівняно 32018 р., а з України до ЄС збільшився на 1,6 млн дол.

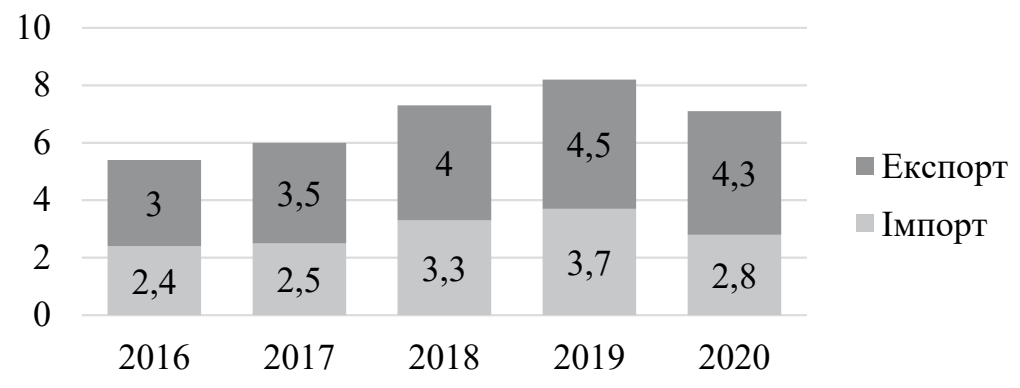

Рис. 4. Зовнішньоторговельний оборот послуг України з ЄС, млрд дол.

Джерело: побудовано авторами за даними [6]

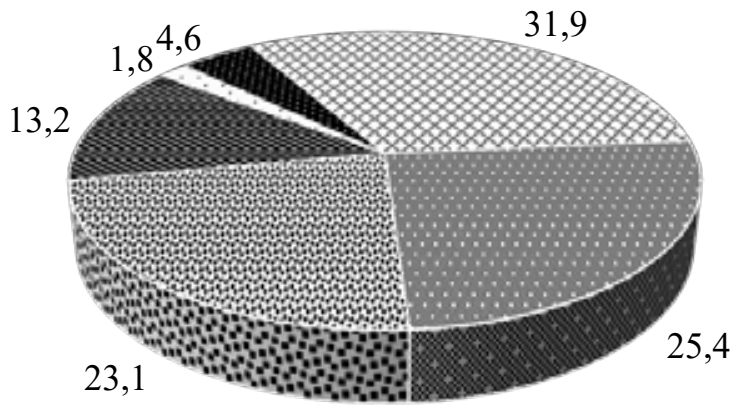

послуги у сфері телекомунікацій

: транспортні послуги

: послуги з переробки матеріальних ресурсів

ғ ділові послуги

послуги 3 ремонту та

технічного обслуговування

" інші

Рис. 5. Основні категорії експорту послуг до ЄС у 2020 р., \% Джерело: побудовано авторами за даними [6] 


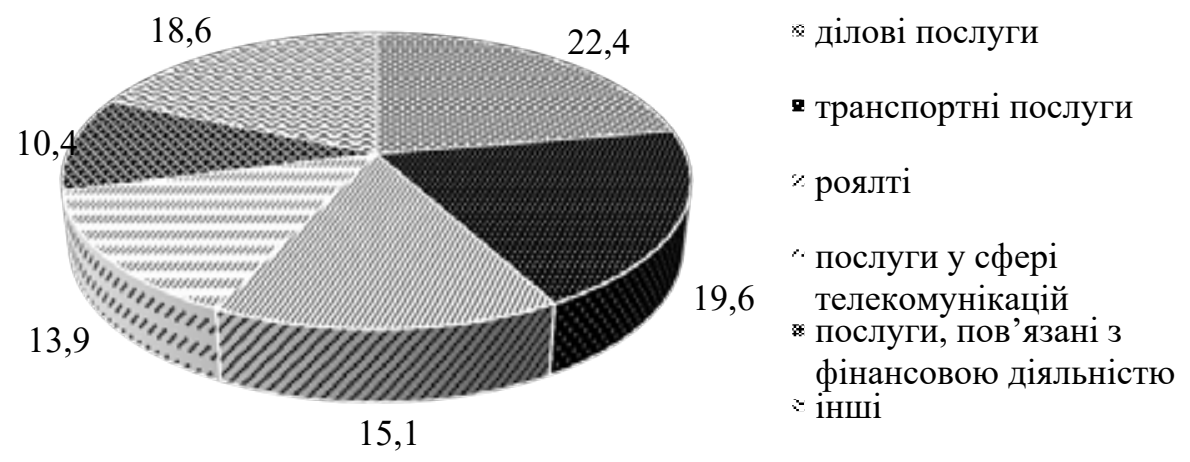

Рис. 6. Основні категорії імпорту послуг з ЄС у 2020 р., \% Джерело: побудовано авторами за даними [6]

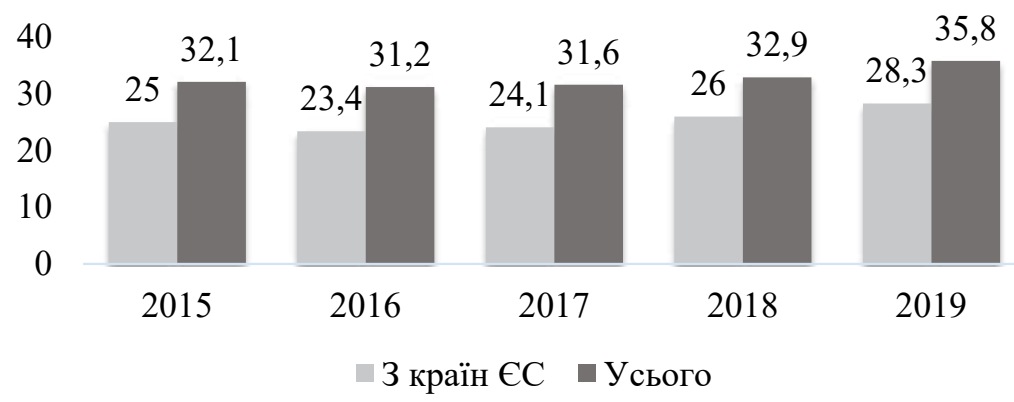

Рис. 7. Обсяг ПЗІ, які надійшли в Україну, млрд дол. Джерело: побудовано авторами за даними [6]

15

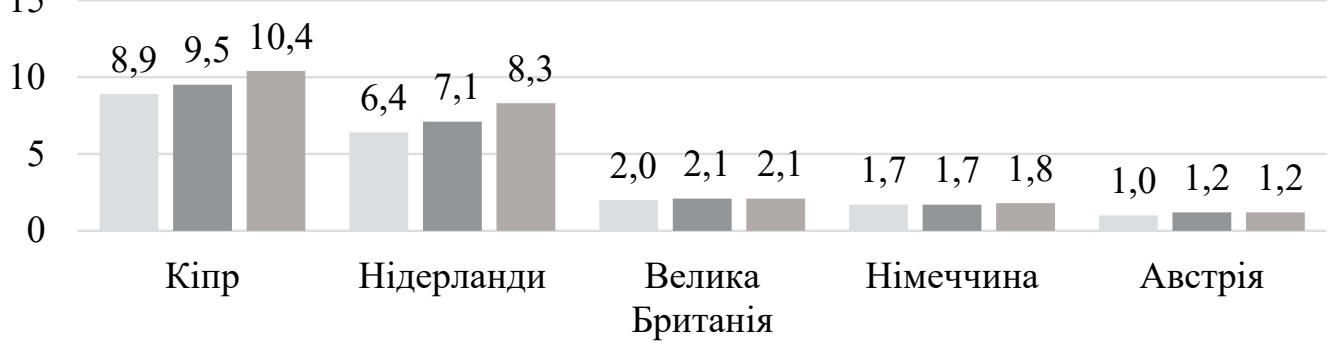

$\square 2017 \backsim 2018 \square 2019$

Рис. 8. Обсяг ПЗІ від найбільших інвесторів України з ЄС, млрд дол. Джерело: побудовано авторами за даними [6]

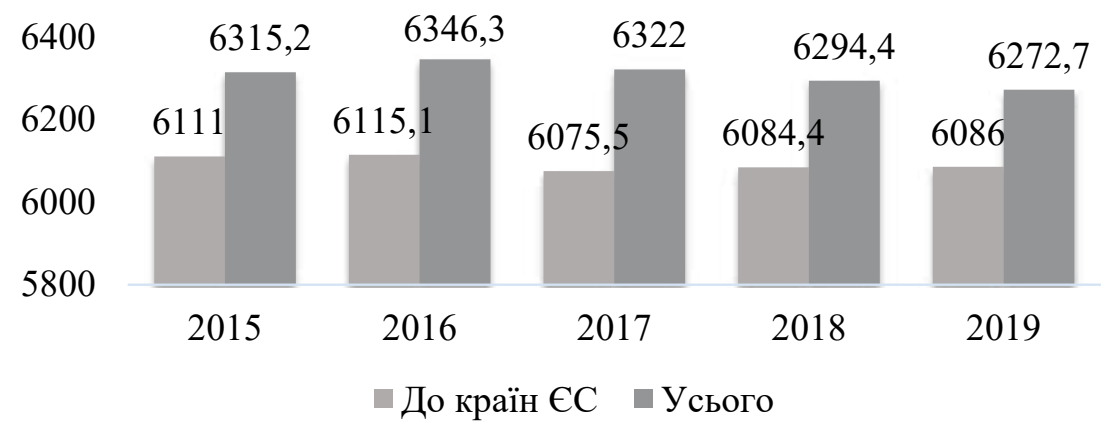

Рис. 9. Обсяг ПII, які надійшли з України, млн дол. Джерело: побудовано авторами за даними [6] 
Таблиця 2

Топ-10 експортерів та імпортерів послуг серед країн ЄС у 2020 р.

\begin{tabular}{|l|c|l|c|}
\hline \multicolumn{1}{|c|}{ Країна-експортер } & $\begin{array}{c}\text { Обсяг експорту } \\
\text { послуг з України, } \\
\text { тис. дол. }\end{array}$ & \multicolumn{1}{|c|}{ Країна-імпортер } & $\begin{array}{c}\text { Обсяг імпорту } \\
\text { послуг в Україну, } \\
\text { тис. дол. }\end{array}$ \\
\hline Німеччина & 613252,7 & Велика Британія & 467468,0 \\
\hline Велика Британія & 580752,6 & Німеччина & 388260,3 \\
\hline Польща & 417896,1 & Ірландія & 261718,3 \\
\hline Кіпр & 387039,2 & Кіпр & 236746,2 \\
\hline Нідерланди & 234789,5 & Польща & 190333,0 \\
\hline Естонія & 195817,2 & Бельгія & 152349,9 \\
\hline Угрщина & 195060,4 & Франція & 125346,5 \\
\hline Данія & 190509,6 & Мальта & 114091,4 \\
\hline Франція & 179788,9 & Австрія & 112021,6 \\
\hline Австрія & 173767,2 & Нідерланди & 110743,9 \\
\hline
\end{tabular}

Джерело: побудовано авторами за даними [6]

ПII (акціонерного капіталу) з України у 2019 р. найбільше надійшло до Кіпру - на 5935,6 млн дол., тобто частка накопичених інвестицій, що надійшли з України, на Кіпрі становить $97,5 \%$.

Отже, ЄС є ключовим торговельно-інвестиційним партнером України, саме тому важливо сприяти розвитку співробітництва з ним.

Пріоритетними напрямами активізації торгівлі України з ЄС є: розширення доступу українських товарів на європейські ринки; проникнення та зміцнення позицій національних виробників на зовнішніх ринках товарів та послуг; посилення конкурентоспроможності української продукції шляхом підвищення її якості; підтримка національних товаровиробників шляхом вдосконалення міжнародноправового механізму захисту їх інтересів; зняття існуючих бар'єрів у торгівлі та поглиблення виробничої кооперації [7].

Можливості інвестиційного співробітництва України з країнами ЄС: відкриття нових ринків для здійснення інвестиційної діяльності, зокрема можливість залучати інвестиції у найпривабливіші ссрери господарювання 3 дешевою робочою силою та наявною сировиною; забезпечення руху капіталу, пов'язаного 3 наданням кредитів, які стосуються торговельних операцій, або з наданням послуг, в яких бере участь резидент однієї зі сторін, а також капіталу, пов'язаного з портфельними інвестиціями і фрінансовими позиками та кредитами інвесторів іншої сторони; створення умов для поліпшення технічного та технологічного стану вітчизняних підприємств за рахунок ПЗІ з країн ЄС і доступу до якісної імпортної техніки та устаткування. В Україні наявні інвестиційно-привабливі фрактори, що сприяють розширенню її інвестиційних зв'язків. До таких належать: великий внутрішній ринок 3 більшістю товарних позицій; розташування основних транспортних шляхів між Європою та Азією; розвинена інфрраструктура; дешева, але кваліфрікована робоча сила [4].

Висновки. Розвиток торговельно-інвестиційних відносин з ЄС у довгостроковій перспективі $€$ одним із пріоритетів зовнішньоекономічної політики України, адже співробітництво між Україною та країнами-членами ЄС сприяє збільшенню обсягів торгівлі й інвестування між обома сторонами. Однак для активізації торговельної та інвестиційної співпраці необхідно удосконалити нормативно-правову базу у сорері торгівлі та інвестицій; здійснити наближення торговельно-інвестиційного середовища України до рівня ЄС; сприяти захисту прав експортерів товарів і послуг та інвесторів на державному рівні; підтримувати національних товаровиробників шляхом вдосконалення міжнародно-правового механізму захисту їх інтересів; мінімізувати існуючі бар'єри та поглибити виробничу кооперацію.

\section{СПИСОК ВИКОРИСТАНИХ ДЖЕРЕЛ:}

1. Бойчук Р. П. Основні засади правового регулювання інвестиційної діяльності в ЄС. Право та інновачійне суспільство. 2015. № 2. С. 22-31.

2. Голіков А. П., Довгаль О. А. Міжнародні економічні відносини : підручник. Харків : ХНУ імені В. Н. Каразіна, 2014. $602 \mathrm{c}$. 
3. Майорова Т. В. Інвестиційна діяльність : підручник. Київ : Центр учбової літератури, 2009. 472 с.

4. Маркевич К. Хто і як інвестує в Україну. Центр Розумкова. URL: https://razumkov.org.ua/statti/khto-i-iakinvestuie-v-ukrainu

5. Новицький В. Є. Міжнародна економічна діяльність України : підручник. Київ : КНЕУ, 2003. 948 с.

6. Офіційний сайт Державної служби статистики України. URL: http://www.ukrstat.gov.ua

7. Романенко В. А., Лебедева Л. В. Зовнішня торгівля України з ЄС: тенденції, проблеми, перспективи. Економіка і суспільство. 2017. № 9. С. 71-77. URL: https://economyandsociety.in.ua/journals/9_ukr/11.pdf

8. Яхно Т. П., Макогін 3. Я. Пріоритетні напрями формування інвестиційної співпраці України із країнами ЄС. Економічний часопис-XXI. 2014. № 5-6. С. 21-24.

\section{REFERENCES:}

1. Bojchuk, R. (2015) Osnovni zasady pravovoho rehuliuvannia investytsijnoi diialnosti v ES [Basic principles of legal regulation of investment activity in the EU]. Pravo ta innovatsijne suspilstvo - Law and innovation society, 2 , 22-31. (in Ukrainian)

2. Holikov, A. P., \& Dovhal, O. A. (2014) Mizhnarodni ekonomichni vidnosyny: pidruchnyk [International economic relations]. Kharkiv: KhNU imeni V. N. Karazina. (in Ukrainian)

3. Majorova, T. V. (2009) Investytsijna diialnist: pidruchnyk [Investment activity]. Kyiv: Tsentr uchbovoi literatury. (in Ukrainian)

4. Markevych, K. (n.d.). Khto i iak investuie v Ukrainu. Tsentr Rozumkova [How invests in Ukraine. Rozumkov Center]. Retrieved from: https://razumkov.org.ua/statti/khto-i-iak-investuie-v-ukrainu (in Ukrainian)

5. Novytskyj, V. Ye. (2003) Mizhnarodna ekonomichna diialnist Ukrainy [International economic activity of Ukraine]: pidruchnyk. Kyiv: KNEU. (in Ukrainian)

6. Ofitsijnyj sajt Derzhavnoi sluzhby ststystyky Ukrainy. Retrieved from: http://www.ukrstat.gov.ua

7. Romanenko, V. A., \& Lebedeva, L. V. (2017) Zovnishnia torhivlia Ukrainy z Yes: tendentsii, problemy, perspektyvy [Ukraine's foreign trade with the EU: trends, problems. perspectives]. Ekonomika $i$ suspilstvo - Economy and society, 9, 71-77. Retrieved from: https://economyandsociety.in.ua/journals/9_ukr/11.pdf (in Ukrainian)

8. Yakhno, T. P., \& Makohin, Z. Ya. (2014) Priorytetni napriamy formuvannia investytsijnoi spivpratsi Ukrainy iz krainamy YeS [Priority areas for the formation of Ukraine's investment cooperation with EU countries]. Ekonomichnyj chasopys-XXI - Economic Journal-XXI, 5-6, 21-24. (in Ukrainian) 